\title{
Rip current generation and management implications in south Florida
}

\begin{abstract}
Miami Beach is one of the most dangerous beaches for rip current drownings in the United States. There are three principal wave generators that result in rip currents: onshore winds associated with high pressure cells, swell waves produced by offshore nor'easters, and tropical storms. A logistic regression analysis showed a correlation between rip currents, wave height and month of the year even under low wave energy conditions at Miami area beaches. Most rips were found to occur during 15-20 knot onshore winds with $0.6-0.9 \mathrm{~m}$ significant wave height. Eleven social, physical and safety factors make Miami Beach a rip current hotspot and pose a major coastal management challenge.
\end{abstract}

Keywords: rip current forecasting, rip current drowning, rip current hot spots, safety factors, beaches
Volume 3 Issue 3 - 2018

\author{
Stephen B Leatherman \\ Department of Earth \& Environment, Florida International \\ University, USA
}

\begin{abstract}
Correspondence: Stephen B Leatherman, Department of Earth \& Environment, Florida International University, I I 200 SW 8th Street, Florida Miami, Florida 33199, USA, Tel I3053482-00, Email Sleat003@Fiu.edu
\end{abstract}

Received: November 16, 2017 | Published: May 31, 2018

\section{Introduction}

South Florida is a tourism destination that is well known for its beaches. Miami Beach is one of the ten most famous beaches in the world and boasts of tens of millions of visitors each year. ${ }^{1}$ At the same time, Miami Beach is the third most deadly beach in the United States ${ }^{2}$ (Table 1). Haulover Park, just north of Miami Beach, is the largest public beach in South Florida, and also prone to rip drownings. ${ }^{3}$ National Weather Service rip forecasts have historically been based on a predictive model developed by Lushine., ${ }^{4,5}$ This deterministic model accounts for wind speed and direction, wave height, and tide level. ${ }^{6}$ Modified the original model to include swell waves generated by offshore storms which has been utilized by Schrader ${ }^{7}$ and Engle ${ }^{8}$ in their studies at Daytona Beach, Florida. The National Weather Service now utilizes a numerical model to predict rip currents in South Florida. The model uses wind and wave data to predict the rip current hazard. The advanced model needs calibration and verification, and field research is needed to provide the necessary data sets. The overall purpose of this research was to determine the meteorological and near shore oceanographic conditions under which rips in South Florida are formed and to identify the factors that cause rip currents at Miami area beaches to be hotspots for rip current drowning. Rip current presence and other pertinent data were collected by lifeguards at Miami Beach and Haulover Beach from January 1, 2016 to June 30, 2016. The daily observations included rip type, flag color, wave height, wave period, sea or swell waves, wave direction, wave breaker type, wind speed, and wind direction. The lifeguards collecting the data were veterans with decades of experience identifying rip currents and examining surf conditions. Furthermore, the lifeguards were informed on how to measure significant wave height (the highest one third of waves) and wave period to obtain more consistent observations. The dataset was statistically analyzed through a logistic regression using State.

\section{Rip generation}

Rip currents in South Florida are primarily generated during fairweather conditions except for those caused by the passing of tropical storms and hurricanes. Locally-generated winds are produced by the Bermuda high pressure cell positioned offshore the mid-Atlantic coast. A 3-4 mb pressure gradient between Jacksonville and Key West is enough to yield 15 to 20 knot onshore winds (Figure 1). Rips are generated by 0.6 to $1.2 \mathrm{~m}$ waves during fair-weather conditions, which seem like perfect beach days, making these rips deceptively dangerous to bathers. Another type of rip generator is nor'easters offshore the mid-Atlantic and Northeast coast, which produce large swells (Figure 2). These swell waves, while infrequent at Miami Beach, can generate strong rips. Palm Beach is far more impacted by swells than Miami Beach because the Bahamas and continuous, large-scale sand shoals protect Miami Beach from most swell waves. There were few swell waves hitting Miami Beach in 2016 because of El Nino, which caused the nor'easters to track further southward, and hence not in the right position to generate swells (Robert Molleda, personal communication, 2016). Offshore tropical storms passing between the Florida peninsula and the Bahamas generate rips. Generally, there are no beach goers in the water during these storms except for a few surfers because the waves reach over $1.5 \mathrm{~m}$ in height. High winds, blowing sand and rain deter bathers. One such event was Hurricane Matthew that paralleled the Florida coastline on October 6-7, 2016. This hurricane produced offshore waves with a significant wave height of $6.4 \mathrm{~m}$ and period of 13 seconds in central Florida (e.g., there are no wave buoys in South Florida but similar wave characteristics would be expected; www.checkthewaves.com). Matthew most certainly generated much stronger rips compared to those measured in this study. ${ }^{9}$ Governor Rick Scott of Florida declared a state of emergency, and Miami Beach was closed with the recommendation that residents evacuate. Therefore, no rip current measurements could be undertaken during this event.

Table I Deadliest beach areas in the United States ${ }^{2}$

\begin{tabular}{lll}
\hline Rank & Beach & State \\
\hline 1 & Pensacola Beach & Florida \\
2 & Panama City Beach & Florida \\
3 & Miami Beach & Florida \\
4 & Ft. Lauderdale Beach & Florida \\
5 & Gulf Shores & Alabama \\
6 & South Padre Island & Texas \\
7 & Myrtle Beach & South Carolina \\
8 & Daytona Beach & Florida \\
9 & Miramar Beach & Florida \\
10 & Navarre Beach & Florida \\
\hline
\end{tabular}




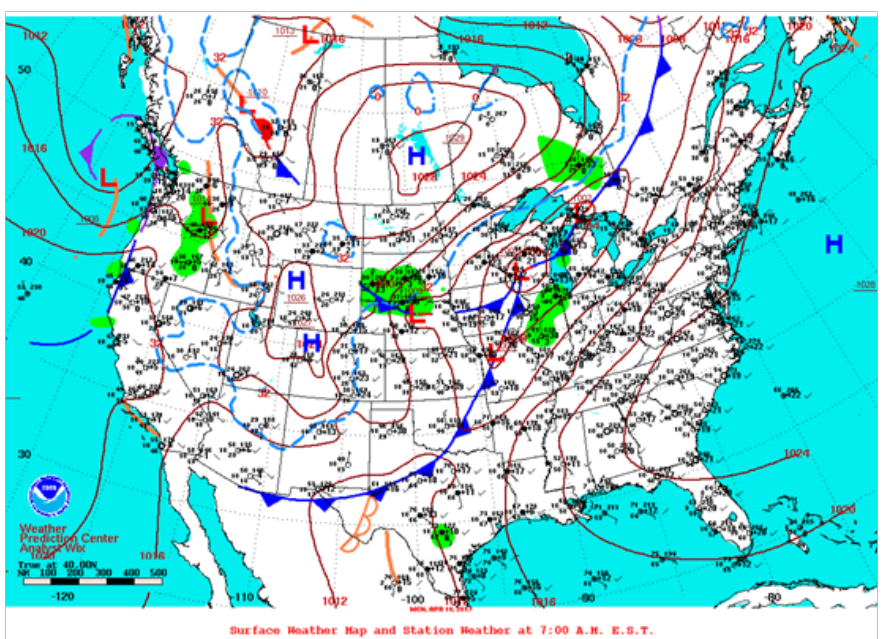

Figure I A Bermuda high pressure cell on April 10,2016, off the mid-Atlantic coast resulted in a pressure difference of $4 \mathrm{mb}$ between the Florida Keys and Jacksonville, which generated a 15-20 knot East wind.

\section{Rip forecasting}

The National Weather Service forecasts rip current hazards; this information is available online and reported by TV meteorologists. Lifeguard observations were compared to the National Weather Service rip current daily forecasts for the six-month period when most rips occur (e.g., winter and early spring). The National Weather Service assigns a value of high, moderate, or low risk of rip currents. During the survey period, 43 high-risk days were recorded (Table 2). The lifeguard observations showed there were rip currents present in either South Beach or Haulover Beach for 35 of these 43 days

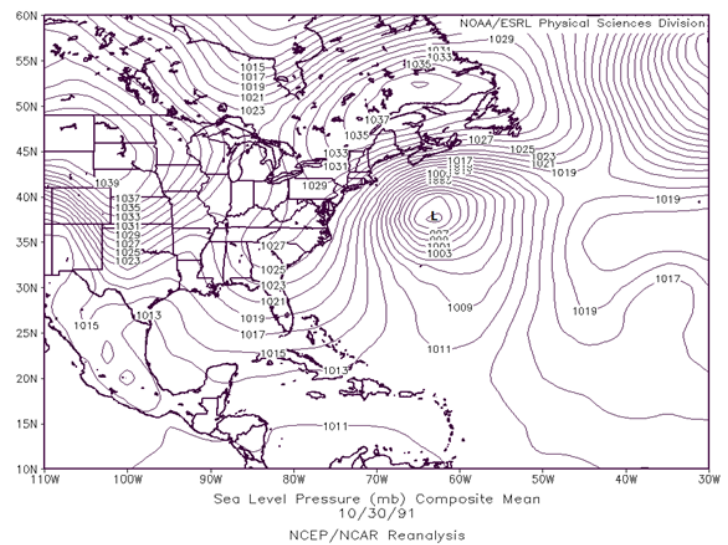

Figure 2 This Nor'easter on October 30, 1991 off the mid-Atlantic coast generated large swell waves that reached South Florida.

or $81 \%$ of the time. Rip currents were present at both locations 21 out of the 43 days, which amounts to $49 \%$ of the time. Furthermore, field measurements of rip currents compare reasonably well with the lifeguard observations and the National Weather Service forecasts based on a limited data set (Table 3). The lifeguards made a total of 285 observations with 171 at Haulover and 114 at Miami Beach (Table 4). Rip currents at Haulover Park Beach were present 47 percent of the time and $30 \%$ of the time at Miami Beach. Haulover tends to have higher wave energy than Miami Beach, which could be caused by wave refraction due to the ebb tidal delta at Haulover Inlet.

Table 2 Rip current presence at Miami Beach and Haulover Park Beach from lifeguard observations during January to June 30, 2016 are compared to the National Weather Service (NWS) high risk days during this time period

\begin{tabular}{llll}
\hline Rip location & Lifeguard observations & NWS high risk days & Percent of agreement \\
\hline Rips at either location & 35 & 43 & 81 \\
Rips at both locations & 21 & 43 & 49 \\
\hline
\end{tabular}

Table 3 Field deployments for rip presence by the research team (9) are compared to lifeguard observations and the National Weather Service rip forecast

\begin{tabular}{llllll}
\hline Field rips & Location & Wind speed (kts) & Rip presence & $\begin{array}{l}\text { Lifeguard } \\
\text { observations }\end{array}$ & $\begin{array}{l}\text { National weather } \\
\text { service rip forecast }\end{array}$ \\
\hline Mar 23 2016 & South Beach & 17 & Yes & Rips Present & High Risk \\
April 10 2016 & South Beach & 15 & Yes & Rips Present & High Risk \\
July 18 2016 & South Beach & 15 & Yes & Rips Present & High Risk \\
Nov 15 2015 & Haulover Park & 17 & No & Rips Present & High Risk \\
April 6 2016 & Haulover Park & 15 & Yes & Rips Present & Low Risk \\
Jun 20 2016 & Haulover Park & 15 & Yes & Rips Present & High Risk
\end{tabular}

Table 4 Rip current presence by location

\begin{tabular}{lll}
\hline Rip by location & Rip occurrence (\%) & Number of observations \\
\hline Haulover & 47 & 171 \\
South Beach & 30 & 114 \\
Total & 40 & 285 \\
\hline
\end{tabular}


Rip currents were found to start 10 to 15 meters offshore instead of close to the shoreline, and no feeder currents were detected. Beaches in south Florida have a fairly gentle slope and a relatively low wave climate. ${ }^{10}$ These offshore-flowing currents are harder to detect because there is little to no suspended sediment in the water column and are slow-moving. ${ }^{9}$ Most rip currents occurred during winter months and early spring. The highest months were February, March and April, and then rip occurrence dropped off in May and June (Table 5). March is typically when U.S. students have Spring Break, which is also a month with a high probability of rip currents and many rip rescues. During the summer, wave heights decline significantly because there are few wave makers except for tropical storms passing just offshore South Florida, which are not common. Wind speeds and wave heights were estimated by the lifeguards during this study period. Most rip currents occurred during 15-20 knot winds, with few observations beyond 20 knots (Table 6). Rips were also observed during calm and low wind speeds, indicating that these waves were either not locally generated or generated by prior wind speeds (e.g., wind speed can drop while waves are still moving onshore). Wave heights had a positive correlation with rip presence. Rip currents were most commonly generated at Miami Beach during wave heights of $0.6 \mathrm{~m}$ to $0.9 \mathrm{~m}$ (Table 7). Larger waves, which are less frequent, can generate stronger rips. ${ }^{9}$ The results of the logistical regression showed positive correlations between rip presence and wind speed, wave height and month of the year, corresponding to the wave calendar (Table 8). Miami Beach and Haulover Park Beach are low wave energy environments where little field research has been conducted compared to the high wave energy coasts of California and Australia. ${ }^{10,11}$

Table 5 Rip current presence by month

\begin{tabular}{lll}
\hline Rip by month & Rip occurrence (\%) & $\begin{array}{l}\text { Number of } \\
\text { observations }\end{array}$ \\
\hline January & 40 & 52 \\
February & 47 & 57 \\
March & 42 & 62 \\
April & 49 & 47 \\
May & 28 & 36 \\
June & 25 & 31 \\
Total & 40 & 285 \\
\hline
\end{tabular}

Table 6 Rip current presence by wind speed

\begin{tabular}{lll}
\hline Rip by wind speed (kts) & Rip Occurrence (\%) & $\begin{array}{l}\text { Number of } \\
\text { observations }\end{array}$ \\
\hline 0 to 3 & 25 & 4 \\
4 to 8 & 14 & 148 \\
9 to 11 & 53 & 34 \\
12 to 15 & 72 & 68 \\
16 to 20 & 91 & 23 \\
\hline
\end{tabular}

Table 7 Rip current presence by wave height

\begin{tabular}{lll}
\hline $\begin{array}{l}\text { Rip by wave height } \\
(\mathbf{m})\end{array}$ & Rip Occurrence (\%) & $\begin{array}{l}\text { Number of } \\
\text { observations }\end{array}$ \\
\hline 0.3 & 52 & 25 \\
0.6 & 42 & 93 \\
0.9 & 66 & 53 \\
1.2 & 81 & 27 \\
Total & & 279 \\
\hline
\end{tabular}

Table 8 The logistic regression statistical analysis shows that wave height, wind speed and time of year have statistically significant impacts on rip current presence

\begin{tabular}{llll}
\hline Month (ref=Jan) & Coefficient & Standard error & P value \\
\hline February & 1.7 & 1.1 & 0.13 \\
March & $\mathrm{I}$ & 1.2 & 0.39 \\
April & 1.6 & 1.4 & 0.25 \\
May & 2.3 & 1.6 & 0.15 \\
June & 3.6 & 1.7 & 0.04 \\
Wave Height & 3.9 & 0.74 & 0 \\
Wind Speed & 0.28 & 0.09 & 0.001 \\
\hline
\end{tabular}

\section{Management implications}

Miami Beach attracts tens of millions of visitors annually and is the \#3 beach for rip current drownings in the United States. ${ }^{2}$ This popular tourist destination has a number of deceptively dangerous factors that make Miami Beach rips so dangerous, which has important management implications (Table 9). Beaches are the number one recreational destination for Americans, and there are more than two billion beach visits per year. ${ }^{1}$ The United States public is primarily informed about rip currents on site via beach hazard flags, where lifeguards post current beach conditions by using different colored flags to represent danger. Many visitors from inland areas lack experience and knowledge of the ocean, and international tourists may not be able to read beach warning signs which are only in English or understand the hazard flag system (Table 9). ${ }^{12}$ This lack of public knowledge contributes to the high annual death toll of rip currents. ${ }^{11}$ Rip currents at Miami area beaches often occur during sunny, fairweather conditions with relatively small waves $(0.6-0.9 \mathrm{~m})$ and a refreshing 15-20 knot onshore breeze (Table 9). This idyllic weather in combination with South Florida's "clear-water" rips leads to a deceptively dangerous place for bathers. ${ }^{9}$ Many bathers associate rip currents with large waves or stormy weather and do not realize that rip currents can occur under blue sky conditions. As the clearwater rips here contain little to no sediment, these offshore-flowing currents are practically invisible to the casual beachgoer. This is a serious management problem-how do you educate beachgoers about rip currents when they are almost impossible to spot? Lifeguards at Miami Beach rescue many bathers annually and are a great asset to beach safety. However, lifeguards are not present along the entire 13 $\mathrm{km}$ coastline of Miami Beach. Furthermore, lifeguards are off-duty at 5 PM, but the beach does not close until sunset (Table 9). Many visitors will come to Miami Beach at $4 \mathrm{pm}$ and leave at sunset to avoid the intense UV radiation of the subtropics, but this puts them at risk of rip currents with no lifeguards present for the majority of their beach visit. 
Table 9 Physical, safety and social factors that have important implications for management at Miami Beach

\section{Social factors}

High population in South Florida

IOs of millions of visitors annually

Some people do not understand or heed warning flags

Abundance of bars and night clubs leading to drinking and bathing

Bathers are typically inexperienced swimmers

\section{Physical factors}

Rips can occur during sunny, fair-weather conditions

Rips generated by moderate onshore winds and non-threatening waves

"Clear-water" rips are nearly invisible

\section{Safety factors}

Sections of Miami Beach have no lifeguards

Signage is only in English

Lifeguards off duty at 5PM, while many people stay until sunset

\section{Discussion}

During El Nino years, storm systems travel farther south so there are more westerly winds in Florida compared to La Nina years. During El Nino years, the wind can shift from west to south and back again very quickly, so the wind does not have a chance to establish an onshore wave field and generate rips. In January, wind direction is much more variable. March is typically when there are stronger east winds. Starting around March to April, high pressure systems off the Atlantic Ocean produce more steady east winds, and this combination of east winds and Spring Break crowds result in many rip rescues and unfortunately some deaths. Bathers should stay close to the shoreline in the shallower water because rip currents typically do not start until 10 to 15 meters offshore unless much larger waves than were observed during this study are encountered, such as during a passing hurricane or large swell generated by a mid-Atlantic nor'easter. The "clear-water" rips of South Florida are very difficult to detect even for lifeguards. It was often necessary for the research team to wade into the ocean and release fluorescein tracer dye to detect an offshoreflowing current. Lifeguards look for floating Sargasso seaweed as the best natural indicator of rip current presence. The lifeguard dataset is useful but more and better-documented data using diagnostic tests for rip currents are necessary. Instrumented measurements are needed daily, particularly by deployment of nearshore wave buoys and/or pressure-transducer wave gauges at the Miami area beaches. It will also be beneficial to place gauges just beyond the series of coral reefs to determine how offshore waves are transformed and attenuated. Lifeguards should employ a proof-positive method of determining rip presence (e.g., tracer dye, water-saturated coconuts as drogues, etc.) A beach field station is needed to safeguard the instrumentation and provide for better and more frequent field measurements such as was undertaken for the dissertation research at Tamarama Beach, Sydney, Australia by Brander ${ }^{13}$ Instrumented, continuous wave measurements are necessary to verify and calibrate the National Weather Service numerical model to confirm their rip current forecasts. This data set would also be important for studying beach erosion and to evaluate beach nourishment projects, which are vital to maintaining this very popular, world-famous beach. ${ }^{14}$

\section{Conclusion}

Rip currents were found to be correlated with wave height and month of the year using a logistic regression analysis. The prevailing thought of many beachgoers is that rip currents occur during stormy conditions, but rips at Miami area beaches are generally "fair-weather killers." Rip currents, which can occur during 15 kt winds (e.g., a moderate onshore breeze) and on warm, sunny days, can be very dangerous even though they are fairly weak. Rips were found to be most commonly generated by relatively small, non-threatening waves (e.g., 0.6 to $0.9 \mathrm{~m}$ in height). Additionally, the "clear-water" rips of South Florida are practically invisible to beachgoers. These physical factors, along with social and safety considerations, pose a significant problem for coastal management. ${ }^{15-17}$

\section{Acknowledgements}

Dr. Keqi Zhang as my major professor has provided guidance and contributed significantly to my dissertation research. Dr. Qing Lai of the Department of Global and Sociocultural Studies assisted in the statistical analysis. I would like to thank Chief Vincent Canosa of the Miami Beach lifeguards and Lt. Matthew Sparling of Haulover Beach for their help in recording surf conditions. I would also like to thank Robert Molleda of the National Weather Service Miami Forecast Office for his counsel. This research was supported by a Florida International University Presidential Fellowship.

\section{Conflict of interest}

There is no conflict of interest.

\section{References}

1. Brander RW. Field observations on the morphodynamics of rip currents. Ph.D thesis, Department of Geography, University of Sydney; 1997. 240 p.

2. Brander R, MacMahan J. Rip Currents: Beach safety, physical oceanography and wave modeling. In: Leatherman SP, Fletemeyer J, editors. Boca Raton, FL: CRC Press; 2011. p. 310.

3. Brannstrom C, Brown HL, Houser, et al. "You can't see them from here": Evaluating beach user understanding of a rip current warning sign. Applied Geography. 2015;56:61-70.

4. Dusek G, Seim H, Hanson J, Elder D. Analysis of rip current rescues at Kill Devil Hills, North Carolina In: Rip Currents: Beach safety, physical oceanography and wave modeling. In: Leatherman SP, Fletemeyer J, editors. Boca Raton, FL: CRC Press; 2011;59-86.

5. Engle JA. Formulation of a rip current forecasting technique through statistical analysis of rip current-related rescues. National Conf. on Beach Preservation Technology. FSBPA. 2003. 81 p.

6. Engle J, MacMahan J, Thieke RJ, et al. Formulation of a rip current predictive index using rescue data. National Conf. on Beach Preservation Technology. FSBPA. 2002:1-14.

7. Houston J. The economic value of beaches- a 2013 update. Shore and Beach. 2013;81(1):3-11.

8. Leatherman SB. Rip current hazard on Florida and South Georgia beaches Shore and Beach. 2015a;83:63-66. 
9. Leatherman SB. Rip Currents in South Florida: A Major Coastal Hazard and Management Challenge. Journal of Coastal Zone Management. 2016;19:431

10. Leatherman SB. Rip Current Measurements at Three South Florida Beaches. Journal of Coastal Research. 2017a;33(5):1228-1234.

11. Leatherman SB. Rip Flow Characteristics and Escape Strategies in South Florida. Shore and Beach. 2017b;85(2):30-34.

12. Leatherman SB. Miami Beach at 100: Where would it be without a beach? Shore and Beach. 2015b;83(4):48.

13. Lushine JB. Forecasting dangerous rip current conditions. Weather service forecast office. USA; 1991. $17 \mathrm{p}$.
14. Lushine JB. Florida rip current deaths forecasts and statistics. In: Leatherman SP \& Fletemeyer J, editors. Rip Currents: Beach safety, physical oceanography and wave modeling. 125-131, Boca Raton, FL: CRC Press; 2011.

15. Paxton C. Atmospheric and ocean conditions and social aspects associated with rip current drownings in the United States. Doctoral dissertation; 2014. 211 p.

16. Reinhart BJ, Pfaff S. Wave analysis for rip current forecasting in Southeast North Carolina. Eastern Region Technical Attachment. 2016. p. 17.

17. Schrader M. Evaluation of the modified ECFL LURCS rip current forecasting scale and conditions of selected rip current events in Florida. M.S. thesis, University of Florida; 2004. 77 p. 